Citation: Castillo-Aguilar, C. C., Chiquini-Medina R. A. \& ChiquiniMedina R. A. (2022). Genetic improvement and its effect on the genetic diversity of habanero chili (Capsicum chinense Jacq.). Agro Productividad. https://doi.org/10.32854/ agrop.v15il.2022

Editor in Chief: Dr. Jorge Cadena Iñiguez

Received: March 3, 2021.

Accepted: December 28, 2021.

Published on-line: February 5, 2022.

Agro Productividad, 15(1). January. 2022. pp: 103-109.

This work is licensed under a Creative Commons Attribution-NonCommercial 4.0 International license.

\section{Genetic improvement and its effect on the genetic diversity of habanero chili (Capsicum chinense Jacq.)}

\author{
Castillo-Aguilar, Grescencio C. ${ }^{1}$; Chiquini-Medina Ramón A. ${ }^{2}$; Ghiquini-Medina Ricardo A. ${ }^{{ }^{*}}$ \\ 1 Colegio de Postgraduados, Campus Campeche, Sihochac, Champotón, Mexico, C.P.24050. \\ 2 Centro de Bachillerato Tecnológico Agropecuario Núm. 169, Hecelchakán, Campeche, México, C.P. \\ 24800. \\ 3 Tecnológico Nacional de México/Instituto Tecnológico de Chiná, Campeche, Campeche, México, C.P. \\ 24520. \\ * Correspondence: ricardochiquini@yahoo.com.mx
}

\begin{abstract}
Objective: To determine the impact of genetic improvement on the maintenance and preservation of the genetic diversity of habanero chili (Capsicum chinense Jacq.).

Methodology: We reviewed topics related to the genetic improvement and diversity of habanero chili. We included historic reviews, as well as interviews with plant breeders and nursery growers of the Yucatán Peninsula. The information thus obtained was classified, analyzed, and discussed.

Results: The introduction and use of hybrids and varieties is affecting the genetic diversity of habanero chili, restricting the cultivation of local varieties and, therefore, the use of the Designation of Origin.

Conclusions: Regional genetic improvement is needed to preserve genetic diversity.
\end{abstract}

Key words: Improvement, Diversity, Varieties, Native.

\section{INTRODUGTION}

Considered a genetic pool center for habanero chili (Capsicum chinense Jacq.), the Yucatán peninsula in Mexico produces around 3,500 tons of fruit per year, 85\% of which is sold fresh and 15\% for industrial use (López-Espinoza et al., 2018). The Yucatán peninsula is characterized by the genetic diversity of habanero chili, which is expressed in the different forms, sizes, colors, tastes, and pungency of native varieties. There are several ways to characterize the variability of chili: phenotypically (Latournerie et al., 2002; TrujilloAguirre and Pérez-Yanes, 2005; Canto-Flick, 2007); isoenzymatically (Corona-Torres et al., 2000); agronomically (Latournerie-Moreno et al., 2015); biochemically (Coutinho et al., 2015; Guzman et al., 2010); and molecularly (López-Espinoza et al., 2018).

Despite various efforts, the genetic diversity of chili is endangered, among other things, as a consequence of the introduction of uncertified seeds, which in many cases are hybrids and may scatter in the peninsular region and reproduce as local genetic materials. In 
addition to this problem, there are no genetic improvement programs that contribute to preserve the genetic resources of habanero chili. Therefore, the objective of this article was to document the impact of genetic improvement and the cultivation of improved habanero chili hybrids and varieties on the maintenance and preservation of its genetic diversity.

\section{MATERIALS AND METHODS}

The information contained in this work is based on the review of bibliographic information regarding the genetic improvement and diversity of habanero chili (Capsicum chinense Jacq). We took into account articles, books, and phone interviews with people involved in the cultivation of this species. We interviewed the main habanero chili plant growers of the peninsula, who supply approximately $70 \%$ of the demand of plants for cultivation: Carlos Burgos of the Invernaderos Ma'Alob Pakal nursery (Tenabo, Campeche); Luis Domínguez Pacheco of the La Nueva Era nursery (Hopelchén, Campeche); Ricardo Julián Cutz of the Viveros Cutz nursery (Suma, Yucatán); and Miguel Ángel Barbosa López of the Vivero Barbosa nursery (Muna, Yucatán). The information for the State of Quintana Roo was provided by the ABC Capsicum company via phone and e-mail. Additionally, plant breeder José Jorge Gerardo Trujillo Aguirre (MSc) provided a historic account on the genetic improvement of habanero chili.

\section{RESULTS AND DISCUSSION}

The production of habanero chili in the Yucatán peninsula started with the exploitation of small areas called mecates $(20 \mathrm{~m} \times 20 \mathrm{~m})$, whose produce was sold locally. The improvement of communication routes and the market's demand for the chili fruit resulted in its intensive exploitation. The fruit of the habanero chili plant is trilocular, top-shaped, and orange-colored when ripe, and has a characteristic smell and burning taste (Trujillo-Aguirre, 2021). Between 1975 and 1982, the Instituto Nacional de Investigaciones Agrícolas (INIA) — now Instituto Nacional de Investigaciones Agrícolas Pecuarias y Forestales (INIFAP) - worked to obtain habanero chili varieties, an activity it resumed in 1992. On a regional level, the Instituto Tecnológico Agropecuario (ITA) of Conkal and the ITA of Chiná, in Campeche, only had research papers and dissertations. In 2002, the Centro de Investigación Científica de Yucatán (CICY) brought a group of researchers together to conduct different types of studies about habanero chili.

The INIA, founded in 1960, started its habanero chili genetic improvement program with a series of harvests of native habanero, according to its taste, color, smell, and pungency in Campeche, Yucatán, Quintana Roo, and Belize (1965-1975). As an output, the INIA edited and published the technical brochure No. 1 SARH-INIA, 1981, under the title "Habanero INIA y Habanero Uxmal, Nuevas Variedades de Chile para la Península de Yucatán" (INIA Habanero and Uxmal Habanero, New Varieties of Chili for the Yucatán Peninsula). This brochure mentions the origin of the improvement material and the selection process used to obtain improved cultivars, as well as its characteristics (Trujillo-Aguirre, 2018; Trujillo-Aguirre et al., 1994). These varieties were created at the experimental field of Uxmal, Yucatán, with materials obtained from individual harvests carried out in commercial plantations of habanero chili native cultivars established 
in Yucatán (lines: Yuc-75-01 and Cam 75-24). On the one hand, the INIA variety was characterized by 54-cm-high plants with three fruits per axil, orange-colored when ripe, $5.1 \mathrm{~cm}$ long, $3.2 \mathrm{~cm}$ wide, and a yield of $19,442 \mathrm{~kg} \mathrm{ha}^{-1}$. On the other hand, the Uxmal variety was characterized by 62 -cm-high plants with four fruits per axil, orange-colored (deep yellow) when ripe, $5.4 \mathrm{~cm}$ long, $3.4 \mathrm{~cm}$ wide, and a yield of $19,578 \mathrm{~kg} \mathrm{ha}^{-1}$. The said varieties were registered in 1981 before the Servicio Nacional de Inspección y Certificación de Semillas (SNICS) (Trujillo-Aguirre, personal communication, 2021). On the same year, technical brochure No. 17 SARH-INIA was edited by Octavio Pozo Campodónico (MSc), National Coordinator of Chilis, who worked at the Huastecas experimental field of INIFAP. Pozo Campodónico mentioned the importance of habanero chili in the Yucatán peninsula and its popularity in other domestic markets (Trujillo-Aguirre, 2018). Years later, in 1984, "Presente y pasado del Chile en México" (Present and Past of Chili in Mexico) was published; this document included the first references to the cultivated area, the yield, and the production of habanero chili.

In late 1989, the presence of a Gemini virus was discovered in the horticultural area of Yucatán; consequently, the INIFAP launched in late 1995 a program to harvest native habaneros, in order to recover and preserve their seed (Gaceta SIIDATEY, 2014). Through a program carried out with the support of the State of Yucatán's government and the involvement of the Fundación Produce Yucatán, the obtained germplasm was used to distribute native seed among those producers who had to establish new plantations. The INIFAP launched a series of efforts — of its sole and exclusive authorship — to obtain improved varieties with the fruit characteristics required by the market, such as resistance and tolerance to virosis (Trujillo-Aguirre, 1994; Gaceta SIIDATEY, 2014).

Towards late 1998, the INIFAP's habanero chili improvement program resulted in the registration of three new varieties: Jaguar, Mayapán, and Calakmul. The Jaguar variety was developed in Tamaulipas and adapted to the conditions of the Yucatán peninsula, is harvested at 120 to 125 days, and has a triangular, orange-colored fruit when ripe. The Mayapán variety, harvested at 120 to 125 days, has a triangular fruit, brilliant green before ripening and orange when ripe; its characteristics are adequate for the fresh market and the industry. This variety was obtained through the mass selection method during the first stages and the single seed descent method during the final process (Trujillo et al., 2006b). The Calakmul variety, harvested at 120 to 125 days, has a triangular fruit, green before ripening and red when ripe; its characteristics are adequate for fresh consumption and potentially industrial use (Figure 1) (Gaceta SIIDATEY, 2014). The Jaguar and Calakmul varieties were obtained by the mass selection method at the beginning and the pedigree selection method at the end (Berny, 2011; Ramírez et al., 2012).

The Jaguar variety was obtained from the habanero chili collection of the Banco de Germoplasma de Chile del Campo Experimental las Huastecas (CEHUAS)-INIFAP, which contains materials native to the Yucatán, Quintana Roo, Campeche, and Veracruz production areas, collected during the 1980's and early 1990's (Ramírez-Meraz et al., 2018). The characterization and morphological description efforts, plus the increasing global demand for habanero chili, were the base for the declaration of designation of origin for this product, published in the Diario Oficial de la Federación (DOF) on June 4, 2010, 
comprising the states of Campeche, Quintana Roo, and Yucatán. This designation was backed by the Norma Oficial Mexicana (NOM-189) (Secretaría de Economía, 2012), the official Mexican standard for the habanero chili in the Yucatán peninsula, which includes specifications and testing methods. It was modified and published in the Diario Oficial de la Federación on February 21, 2018.

The boost to the production of habanero chili in the Yucatán peninsula entailed a genetic erosion problem, caused by the introduction of variety and hybrid seeds, together with the practice of harvesting ripe fruits and scattering them by means of multiplication, a practice resulting from ignorance and novelty.

In a personal communication, Trujillo (2021) mentions that, in 2006, a batch of 76 introduced varieties of habanero chili with different colors and tastes were planted in the community of Muna, Yucatán. The aim was to elaborate a production scheme based on the idea of obtaining seeds out of the best harvested fruits and saving them for the next cycle (Figure 2). The adoption of this practice is feasible only for self-sufficiency purposes, not for production schemes. Around the same time, seedlings in germination trays were offered to producers, but without any reference on the material they would plant in their fields. Another institution involved in genetic improvement in Yucatán is the Centro de Investigación Científica de Yucatán (CICY) which, based on the genetic diversity of habanero chili in the peninsula, in 2002 launched a genetic improvement program based on harvests carried out in the region.

Peninsular: it started with 58 initial characterized accessions which were subsequently reduced to 38 . The genetic improvement method chosen was phenotypic mass selection,
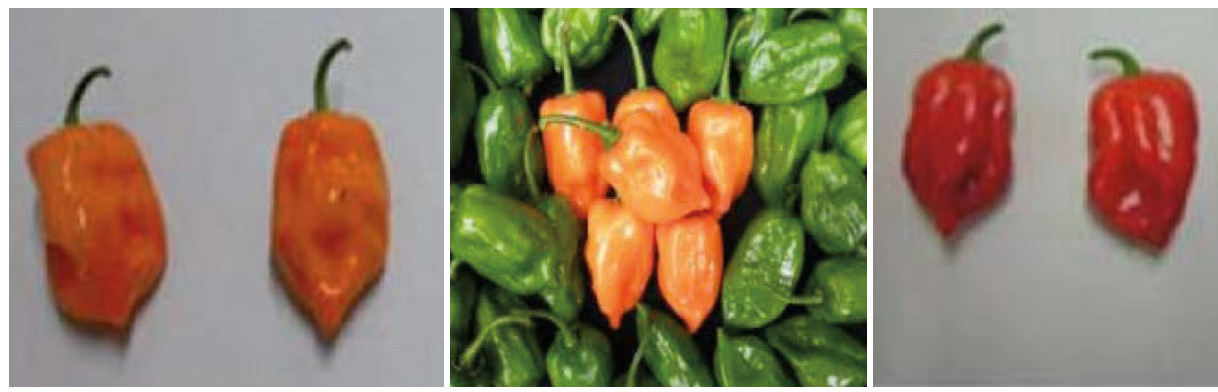

Figure 1. From left to right, Mayapán, Jaguar, and Calakmul INIFAP varieties.
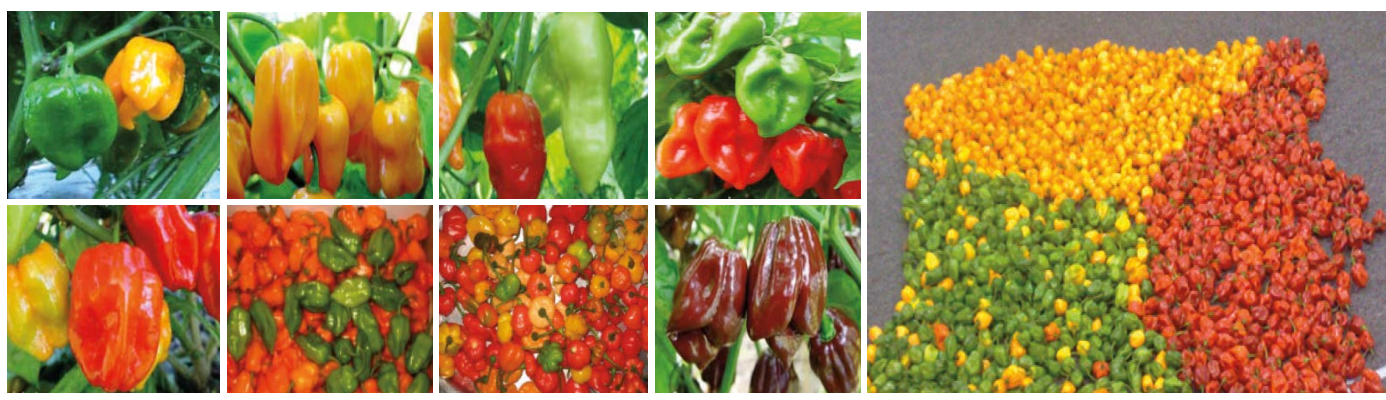

Figure 2. Morphological variability of habanero chili, expressed as fruit color and form, starting from 1994. 


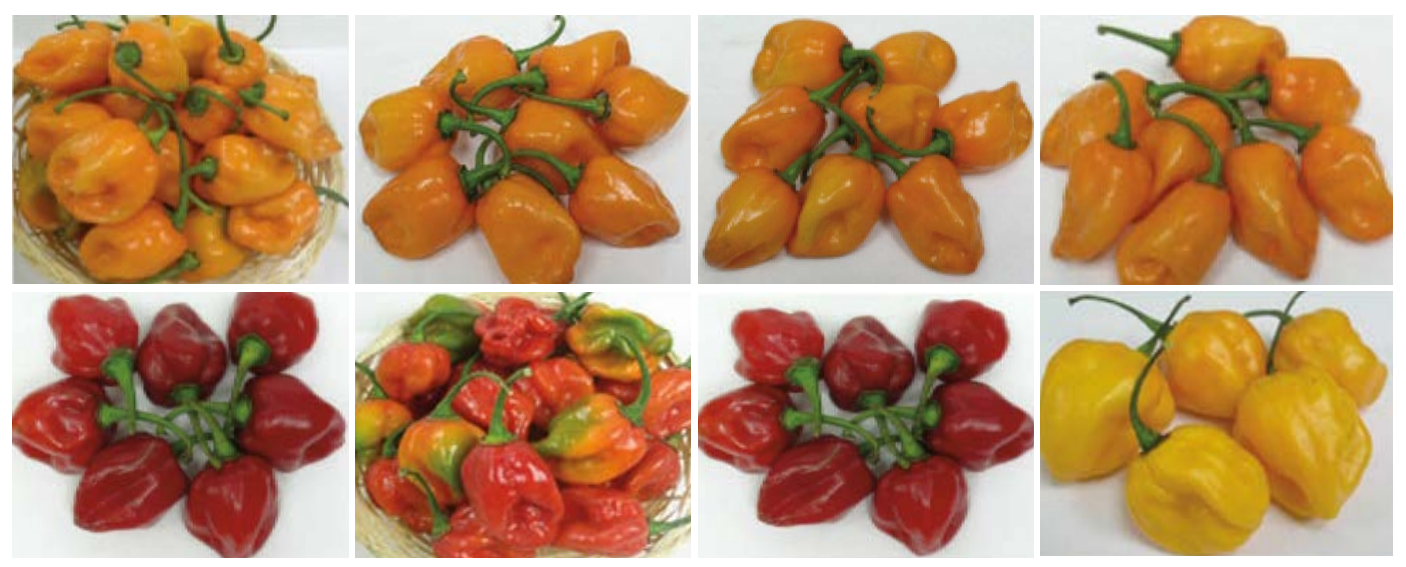

Figure 3. Characterized varieties of the GICY at the SNICS. From top to bottom and from left to right: mayan Ixchel, mayan ba'alche, mayan kauil, mayan ek, mayan chac, mayan chan, mayan kisin, and mayan k'iin.

which consists in selecting a number of plants with the desired characteristics (morphotype) among a certain population, applying a specific selection pressure in each cycle. In total, five selection cycles were used, and the resulting varieties were: mayan Ixchel, mayan ba'alche, mayan kauil, mayan ek, mayan chac, mayan chan, mayan kisin, and mayan k'iin (Santana-Buzzy et al., 2018).

In spite of the genetic improvement programs in the Yucatán peninsula, according to data provided by the habanero chili plant producers in 2021, production is based on the cultivation of introduced varieties and hybrids, such as PX 11459057, which represents between $70 \%$ and $80 \%$ of production in the states of Yucatán and Campeche. Rey Pakal and Palenque, as well as Chichenitza and Helios (5\%) are also among the most used materials.

Production in the State of Quintana Roo is based on the use of the Jaguar, Mayapán, and Mayan Chan varieties. In Yucatán, only the CICY produces small quantities of locally-adapted seeds. The INIFAP Yucatán does not report an improvement program in the peninsula and the seed for its varieties comes from the INIFAP Tamaulipas.

To date, the CICY has a habanero chili germplasm bank with 250 accessions. It is important to preserve, characterize, and protect the habanero chili genetic diversity in germplasm banks, considering samples of populations grown by several generations of regional producers. Genetic improvement programs must not include materials that have been introduced and reproduced in the Yucatán peninsula.

The chosen selection method results in a high genetic uniformity among the new varieties. In fact, it is considered the best method for autogamous species, such as habanero chili, for in spite of being a very long improvement process, it is very efficient to obtain varieties with a high genetic value. The mass, individual, crossbreeding, and pedigree selection methods have the least impact on regional genetic diversity, and use diversity within and among populations.

In this respect, as part of their assessment of different populations of habanero chili, López- Espinosa et al. (2018) found an intermediate diversity among the studied populations. These authors add that genetic differentiation among habanero chili populations in the Yucatán peninsula is low, which means that most genetic diversity (95.5\%) is represented 
among the populations. Improved varieties are mostly hybrids and are not allowed in the DO, since they do not meet the NOM-189 criteria for the habanero chili in the Yucatán peninsula. Hence the need of a genetic improvement program that focuses on generating improved native varieties that are able to compete with introduced genotypes.

The use of NOM-189 certified and protected varieties is suitable to monitor traceability in production and certification, as well as compliance by Mexican certification bodies such as ANCE (Asociación de Normalización y Certificación A.C.), EMA (Entidad Mexicana de Acreditación), and IMPI (Instituto Mexicano de Protección Intelectual), regarding the designation of origin or collective brand (Marca Colectiva), as proposed by the Área de Normalización de la Secretaría de Agricultura, Ganadería, Desarrollo Rural, Pesca y Alimentos (SAGARPA).

\section{GONGLUSION}

The Yucatán peninsula needs a genetic improvement program to produce habanero chili native varieties whose characteristic form, scent, color, and taste allow them to achieve competitive yields and preserve genetic diversity.

\section{ACKNOWLEDGEMENTS}

We are indebted to Jorge Gerardo Trujillo (MSc) for the invaluable information he contributed to this article.

\section{REFERENGES}

Aguilar- Rincón. V. H., Corona-Torres, López-López P., Latournerie- Moreno L., Ramírez -Meraz M., Villalón- Mendoza H., Aguilar -Castillo J. A. (2010) Los chiles de México y su Distribución. SINAREFI, Colegio de Postgraduados, INIFAP, IT-Conkal, UANL, UAN. Montecillo, Texcoco, Estado de México. $114 \mathrm{p}$

Canto- Flick A. (2007). Caracterización morfológica y determinación de los niveles de capsaicina en 18 accesiones de chile habanero (Capsicum chinense Jacq.) Tesis Instituto Tecnológico de Mérida. Maestro en Ciencias en Ingeniería Bioquímica. Mérida, Yucatán, México.

Corona-Torres T., García-Velázquez A., Castillo-González F., Montero-Tavera V., Azpiroz-Rivero H. S. (2000) Caracterización isoenzimática de la diversidad genética de colectas de chile (Capsicum annuum L. y Capsicum chinense Jacq.). Revista Chapingo Serie Horticultura 6:5-17,

Coutinho, J. P., Barbero, G. F., Avellán, O. F., Garcés-Claver, A., Godoy, H. T., Palma, M., \& Barroso, C. G. (2015). Use of multivariate statistical techniques to optimize the separation of 17 capsinoids by ultra performance liquid chromatography using different columns. Talanta, 134, 256-263.

Gaceta SIIDETEY. 2014. Investigación del INIFAP en chile habanero. Organo oficial de la ciencia y tecnología del estado en Yucatán Año 6 numero 14

Godínez-Hernández, Y., Anaya-López, J. L., Diaz-Plaza, R., González-Chavira, M., Torres-Pacheco, I., Rivera-Bustamante, R. F., Guevara-González, R. G. (2001). Characterization of resistance to Pepper Huasteco Geminivirus in chili peppers from Yucatan, Mexico. HortScience, 36, 139-142.

Guzman, I., Hamby, S., Romero, J., Bosland, P. W., \& O’Connell, M. A. (2010). Variability of carotenoid biosynthesis in orange colored Capsicum spp. Plant Science, 179(1-2), 49-59.

González-Estrada. T. Gutiérrez, L., Contreras, F., Peraza, S., Xool. E., Trujillo-Aguirre. J. J. G. en II Reunión Estatal de Investigación Agropecuaria, Forestal y Pesca. Fundación Produce Yucatán A.C. 20, 21 Y 22 de enero 2005. pag 279, 283.

Latournerie-Moreno. L., Chávez-Servia J. L.., Pérez-Pérez M.., Castañón- Nájera.G., Rodríguez Herrera S. A.., Arias Reyes L. M.,Ramírez-Vallejo P. (2002). Valoración in situ de la diversidad morfológica de chiles (Capsicum annuum L. y Capsicum chinense Jacq.) en Yaxcabá, Yucatán. Revista Fitotecnia Mexicana 25:25-33. 
Latournerie-Moreno L., López-Vázquez J. S., Castañón-Nájera G., Mijangos-Cortéz J. O., Espadas-Villamil G., Pérez-Gutiérrez A. Ruiz-Sánchez E. (2015) Evaluación agronómica de chile habanero (Capsicum Chinense Jacq.). Agroproductividad 8:24-29.

López-Espinosal S. T, Latournerie -Moreno L., Castañón-Nájera G., Ruiz-Sánchez E., Gómez-Leyva J. F., Andueza-Noh R. H., Mijangos-Cortés J. O.. 2018. Diversidad genética de chile habanero (Capsicum chinense Jacq.) MEDIANTE ISSR. Rev. Fitotec. Mex. Vol. 41 (3): 227 - 236

Santana-Buzzy N., Canto-Flick A., Balam-Uc E., Avilés-Viñas S., Zetina-Rosado G., Montalvo-peniche M.C-, Valle-Gough R., Bello-BelloJ., Lecona-Guzmán C., Solís-Marroquín ., Gómez-Uc E., MuñozRamírez L., Peña-Yam L., Pérez-Pastrana J., Guzmán-Antonio A. 2018. Mejoramiento genético del chile habanero: selección y registro de variedades mejoradas. En: Mejoramiento genético del chile habanero de la península de Yucatán. González-REstrada T., Zúñiga-Ahuilar J.J. Vázquez-Flota T. Compiladores. CONACYT-GICY. Mérida-México

Secretaría de Economía (2012) Norma Oficial Mexicana NOM-189- SCFI-2012, Chile Habanero de la Península de Yucatán (Capsicum Chinense Jacq.) Especificaciones y Métodos de Prueba. Diario Oficial de la Federación, Primera Sección. México, D.F. 30 de diciembre de 2012

Trujillo-Aguirre J.J.G., Pérez-Lianes, G.R. (2005) Caracterización de nueve materiales de Chile Habanero en Muna, Yucatán. México. 43 pp.

Trujillo-Aguirre J.J.G., Díaz-Plaza R. 1994. Society for Tropical Horticulture Interamerican. “Obtencion de cultivares de chile habanero con buenas características horticolas y con tolerancia a la virosis transmitida por mosquita blanca". Campeche, Camp. 13 al 19 Nov. de 1994.

Trujillo -Aguirre J J G. 2018. Caracterización de los recursos genéticos de Capsicum chinense Jacq. en la Península de Yucatán en: Mejoramiento genético de chile habanero de la península de Yucatán Tomas González-Estrada, Jose Juan Zuniga Aguilar, Felipe Vazquez Flota editores CICY.pag. 45-51.

Ruiz-Sánchez E., Gómez-Leyva J F., Andueza-Noh R H., Mijangos-Cortés J. O. 2018. Diversidad Genética de Chile Habanero (Capsicum chinense Jacq.) Mediante ISSR Rev. Fitotec. Mex. Vol. 41 (3): 227 - 236.

Vera-Sánchez K. S., Cadena-Iñiguez J, Latournerie-Moreno L., Santiaguillo-Hernández J. F., RodríguezContreras A., Basurto-Peña F. A., Castro-Lara D., Rodríguez-Guzmán E., López-López P., RíosSantos E. (2016). Conservación y Utilización Sostenible de las Hortalizas Nativas de México. Servicio Nacional de Inspección y Certificación de Semillas. México, D. F. 132 p. 